\title{
The Impact of Headmaster Leadership and Teacher Success on Quality Education
}

\author{
Fatkul Hadi ${ }^{1 *}$, Edi Harapan ${ }^{2}$, Tahrun² \\ ${ }^{1}$ Korwil Dikbud Plakat Tinggi, Indonesia \\ ${ }^{2}$ Universitas PGRI, Palembang, Indonesia \\ ${ }^{*}$ Corresponding author. Email: fatkulhadi.c1@gmail.com
}

\begin{abstract}
The goal of this review is to evaluate and examine the impact of Principal Leadership, Teacher Performance on the Quality of Education at SMP Negeri in the Plakat Tinggi District. This type of study is quantitatively descriptive. The sample in the study consisted of 57 respondents with data collection techniques in the form of a questionnaire. Results have shown that: 1) there is a significant influence on the quality of education by primary leadership; 2) there is a significant impact on the quality of education by teacher performance, and 3) there is a significant influence on the quality of education between main leadership and teacher effectiveness.
\end{abstract}

Keywords: Principal Leadership, Teacher Performance, Education Quality

\section{INTRODUCTION}

Leadership is the capacity to manipulate a group towards the achievement of predetermined objectives. Leadership has a strong effect on organizational growth. The standard of a leader is often considered to be the most significant factor determining the performance of an organization. Successful leaders are able to impact their followers with greater optimism, trust, and dedication to predetermined organizational objectives. As a result, every leader is obliged to pay serious attention to cultivating, mobilizing and guiding all future employees in their atmosphere in order to achieve organizational cohesion and improve employee efficiency in the direction of organizational objectives.

The Headmaster is a source of inspiration to teachers, staff and students. Therefore, the principal must always inspire excitement and self-confidence among teachers, staff and students to embrace and appreciate the objectives of the school with enthusiasm and to work responsibly towards achieving the objectives of the school. The Headmaster, as the leader of the educational institution, shall serve as the person in charge of all educational activities in the school [1].

Mangkunegara [2] clarified that the Principal has the flexibility to handle all the resources it has so that there is a substantial improvement in quality and efficiency in the provision of quality learning facilities for the advancement of students. Coaching is an initiative, action and operation that is carried out in an effective manner in order to produce positive results. The achievement of quality work outcomes requires the participation of the leader. Leaders must provide direction to subordinates so that they can operate efficiently and effectively to ensure that the work generated is of high quality. The presence of coaching job discipline by the principal of educators is required to make the objectives that have been designed work well. The key role of creating quality education through learning activities is to enhance the performance of teachers in schools.

As far as the performance of a school is concerned, it is simply the quality and efficacy of the appearance of the chief, in this case the principal. The Headmaster need to have clear leadership quality standards, because school success can only be accomplished by the quality leadership of school principals. Key leadership is the commitment made and the outcomes that can be obtained by the Principal in the execution of school management in order to achieve educational objectives effectively and efficiently, productively and responsibly [3]. The Headmaster has the authority and policies to raise the quality of education as a leader [4].

Previous research by Fransiska, et al [5] claimed that the performance of the teacher would be high if the leadership style of the principal is successful and if the teacher also has a high work discipline. Teacher success can be optimized with the Principal's style of leadership 
that can motivate teachers to provide high school discipline so that they can always display their best performance in achieving school goals. The results of this study therefore support the view that the relationship between the innovative leadership of the school principals at SD Negeri Rambang Kapak Tengah and the teaching job discipline has a positive direct impact on the performance of teachers.

Subsequent research by Kartini, et al [6] explains that the performance of teachers is the ability of teachers to carry out an operation and to perfect it according to their responsibilities with results as planned. Teacher success is the job that teachers should do in their learning activities in compliance with their respective authorities and obligations in order to achieve school objectives. Quality is a requirement that must be known and validated to certain parties to assess the degree of achievement of the Agency's results in relation to the vision of the organization or business and to the positive and negative effect of the policy.

Based on preliminary observations and interviews with teachers working at SMP Negeri in the Plakat Tinggi District, the Principal is always trying to improve the performance of the faculty so that they have the ability to achieve optimal results, and the information obtained by the researchers on the leadership of SMP Negeri Plakat Tinggi is good enough. On the other hand, however, the willingness of teachers to always enhance their output is still poor. From the results of the researchers' interviews with several teachers at SMP Negeri in the Plakat Tinggi District at the initial observation stage, the researchers concluded that they were still very weak in the preparation and implementation of the learning tools used in the classroom when teaching and learning activities took place. Besides that, on the other hand, the Headmaster is always trying to improve their performance.

Improving the quality of education requires collaboration between school principals and school environment elements. The educational approach is a public process [7]. As school leaders with professional educational management skills, the Headmaster is expected to be able to develop effective school programs, create a favorable school climate, build performance, monitor and evaluate the day-to-day activities of teachers and be able to guide teachers in the implementation of the learning process. The task of educating teachers has different characteristics and behaviors in the learning process and in the performance of teaching duties.

Rusyan's [8] view is that "the behavior of teachers in the learning process is merely conveying material, does not care whether the students understand or not, does not recognize and understand the needs of their students, lacks mastery of learning tools, teachers who often skip truant, come not on time" Teacher conditions like this are a problem for every institution of formal education. With low-performance teachers, schools may find it difficult to produce the desired results. Successful teachers can also create high learners [9]. Performance will be achieved when the Principal communicates, coordinates and supervises on a regular basis.

The low standard of education in Indonesia is one of the four major problems of education found since the 1960s. Attention to education is very high, but, considering the many attempts that have been made, it seems that the question of quality education has not yet been resolved. Complaints about the lower quality of graduates are still echoing. Graduates of primary, junior and high school have not been able to reason and think objectively, and are still reliant on teachers [10]. The capacity of students to be autonomous has not been realized, so that the students' initiative to initiate something is not too frequently identified.

In this circumstance, the experience factor would have a huge effect on the leadership of the principal. Experience as a teacher, as a vice-principal of a school, or as a member of a community group profoundly affects the capacity of the principal to carry out his or her work, as well as the preparation and progress that he or she follows. At present, however, the recruitment of school principals is based solely on the policies of those persons in such a way that this occurs. The professionalism of the theory is also also in question. Thus, on the basis of the context to this issue, the researcher reviewed a study entitled " The Impact of Headmaster Leadership and Teacher Success on Quality Education"

\section{METHODS}

According to Sukmadinata [11], the research method is a collection of methods or practices for conducting research based on basic assumptions, philosophic and ideological beliefs, questions and issues at hand. The research approach has a particular design for research. This research approach is quantitative research by explaining the results of the research.

Quantitative analysis is based on the theory of positivism, which emphasizes empirical phenomena and is quantitatively studied. The sample in this study is SMP Negeri Plakat Tinggi District, which is sampled in this study using objective sampling, i.e. teachers who are used as test samples are teachers in each primary school with a total of 57 teachers. Techniques are required for the collection of data, both techniques for the provision of data and techniques for the classification of data that have been collected. The same argument has also been made by Sugiyono [12] that the data collection approach is the method used to collect data, while the data collection technique is the method used to carry out the method chosen to use questionnaire 
data and documentation. The data analysis method used in this study clear correlation and multiple regression data analysis techniques with the aid of the SPSS For Windows Version 22 software. The implementation process of the research included: (1) a descriptive analysis, (2) a test of the analysis criteria and (3) a test of the hypothesis.

\section{RESULTS AND DISCUSSION}

After testing the data analysis criteria, namely the normality test and the homogeneity test, the hypothesis test was continued. After the data are declared to have met the criteria to be checked, the hypothesis is tested using the t-test and the F-test to assess the effect on the variables to be tested in part and at the same time.

Table 1. Results of Multiple Correlation Statistical Analysis and Coefficient of Determination

\begin{tabular}{|l|c|r|r|r|}
\hline \multicolumn{5}{|c|}{ Model Summary $^{\mathbf{b}}$} \\
\hline Model & $\mathrm{R}$ & R Square & Adjusted R Square & Std. Error of the Estimate \\
\hline 1 & $.702^{\text {a }}$ & .493 & .474 & 10.785 \\
\hline a. Predictors: (Constant), Teacher Performance $\left(\mathrm{X}_{1}\right)$, Headmaster Leadership $\left(\mathrm{X}_{2}\right)$ \\
\hline
\end{tabular}

Table 2. F Test

\begin{tabular}{|c|c|c|c|c|c|c|}
\hline \multicolumn{7}{|c|}{$\mathrm{v}$} \\
\hline \multicolumn{2}{|c|}{ Model } & Sum of Squares & df & Mean & $\mathrm{F}$ & Sig. \\
\hline \multirow[t]{3}{*}{1} & Regression & 6100.001 & 2 & 3050.001 & 26.222 & $.000^{\mathrm{a}}$ \\
\hline & Residual & 6281.051 & 54 & 116.316 & & \\
\hline & Total & 12381.053 & 56 & & & \\
\hline \multicolumn{7}{|c|}{$\begin{array}{l}\text { a. Predictors: (Constant), Teacher Performance (X1), Headmaster Leadership } \\
\text { (X2) }\end{array}$} \\
\hline \multicolumn{7}{|c|}{ b. Dependent Variable: Quality Education (Y) } \\
\hline
\end{tabular}

Table 3. Test Statistics $\mathbf{t}$

\begin{tabular}{|c|c|c|c|c|c|c|}
\hline \multicolumn{7}{|c|}{ Coefficients $^{\mathrm{a}}$} \\
\hline & \multirow{2}{*}{ Model } & \multicolumn{2}{|c|}{ Unstandardized Coefficients } & \multicolumn{3}{|c|}{ Standardized Coefficients } \\
\hline & & B & Std. Error & Beta & $\mathrm{t}$ & Sig. \\
\hline \multirow[t]{3}{*}{1} & (Constant) & 25.337 & 9.382 & & 2.701 & .009 \\
\hline & Teacher Performance (X1), & .465 & .146 & .446 & 3.192 & .002 \\
\hline & Headmaster Leadership (X2) & .287 & .130 & .308 & 2.204 & .032 \\
\hline
\end{tabular}

Based on the results of the review of the research data mentioned in SPSS version 22. Before the study was carried out, the data criteria were first tested, namely the validity test and the reliability test. The data validity test was carried out using the validation test carried out with the validator, namely the PGRI Palembang University lecturer. Then proceed to verify the validity of the analysis using the SPSS software version 22 estimate. The results of the research validity measurement for the key leadership variable suggest that they are all correct so that the items of the argument can be further checked. The results of the study validity measurement for the teacher output variables note that all of them are correct so that the statement items can be further checked. The results of the validation analysis calculation for the quality variables of education note that all of them are correct so that the items of the argument can be further checked. The pre-requisite data test would then be continued for the reliability test. After measurement using the SPSS version 22 program, it is known that the key leadership variable had a value greater than the $\mathrm{r}$ table, that the teacher performance variable was greater than the $\mathrm{R}$ table, and that the instructional quality variable had a value greater than the $\mathrm{R}$ table, so that it could be assumed that all the research variables had been defined.

\section{CONCLUSION}

Due to the results of the research that has been carried out, it can be concluded that the leadership of the Principal has an influence on the quality of education based on the results of the t-test analysis. This shows 
that the influence of the Principal's leadership on the quality of elementary school education in the Plakat Tinggi sub-district has responded to the first hypothesis. Teacher performance has an impact on the quality of education based on the results of the t-test analysis. This shows that the effect of teacher performance on the quality of education at SMP Negeri in the Plakat Tinggi District has been answered by the second hypothesis. Headmaster Leadership and Teacher Performance have a joint impact on the quality of education based on the results of the F-test analysis. This shows that the effect of Principal Leadership and Teacher Performance at the same time on the quality of education at SMP Negeri in the Plakat Tinggi District responded to the third hypothesis.

\section{AUTHORS' CONTRIBUTION}

Fatkul Hadi: designed and performed experiments and analysed data. Edi Harapan and Tahrun: Proofing.

\section{ACKNOWLEDGMENTS}

Thank you to your family and friends, the Chancellor of the PGRI Palembang University, the Director of the PGRI Palembang University Postgraduate Program, the Chair of the PGRI Palembang University Education Management Masters Program and the supervisors who have contributed to the completion of this thesis journal.

\section{REFERENCES}

[1] Agustina, M., Kristiawan, M., \& Tobari. (2021). The Influence of Principal's Leadership and School's Climate on The Work Productivity of Vocational Pharmacy Teachers in Indonesia. International Journal of Educational Review 3(1), 63-76.

[2] Mangkunegara, P. A. (2014) Manajemen Sumber Daya Manusia [Human Resource Management]. PT.remaja Rosdakarya: Bandung.

[3] Mulyasa. (2013). Pengembangan dan implentasi pemikiran kurikulum [Development and implementation of curriculum thinking]. Bandung: Rosdakarya.

[4] Asvio, N., Yamin, M., \& Risnita. (2019). Influence of Leadership Style, Emotional Intelligence and Job Satisfaction toward Organizational Commitment (Survey at SMA Muhammadiyah South Sumatera). International Journal of Scientific \& Technology Research 8 (8).

[5] Fransiska.W, Harapan.E \& Tahrun (2020). Pengaruh Kepemimpinan Visioner Kepala Sekolah dan Disiplin Guru terhadap Kinerja Guru Sekolah Dasar [The Effect of Principal Visionary
Leadership and Teacher Discipline on Primary School Teacher Performance]. Journal of Education Research, 1(3), 2020, Pages 308-316.

[6] Kartini, Ahmad. S, Eddy. \& S (2020). Pengaruh Gaya Kepemimpinan Kepala Sekolah dan Komunikasi Interpersonal Terhadap Kinerja Guru [The Effect of Principal Leadership Style and Interpersonal Communication on Teacher Performance]. Journal of Education Research, 1(3), 2020, Pages 290-294.

[7] Maseleno, A., Ayshwary, B., Ivanova, T. N., Hashim, W., Nguyen, P. T., Shankar, K., Kristiawan, M., Huda, M. (2019). General Theoretical and Philosophical Aspects of Modern Education. Aspectos Teóricos y Filosóficos Generales de la Educación Moderna. Revista San Gregorio 2019, No. 32 Special Issues August.

[8] Rusyan, A. T. (2013). Proses Pembelajaran yang Efektif [Effective Learning Process]. Bandung: Bima Budhaya.

[9] Hanim, H., \& Rahmadoni, J. (2020). Determination of Lecturer Reception Using Analytical Hierarchy Process (AHP). Journal of Applied Engineering and Technological Science (JAETS), 1 (2), 136141.

[10] Nasution. (2010). Berbagai Pendekatan dalam Proses Belajar dan Mengajar [Various Approaches in the Learning and Teaching Process]. Jakarta: Bumi Aksara.

[11] Sukmadinata, N. S. (2015). Metode Penelitian Pendidikan [Educational Research Methods]. Bandung: Remaja Rosdakarya.

[12] Sugiyono. (2018). Metode Penelitian Kuantitatif [Quantitative Research Methods]. Bandung: Alfabeta. 